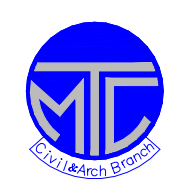

ICCAE

Military Technical College

Kobry Elkobbah,

Cairo, Egypt

\author{
6hㅡ International Conference \\ On Civil \& Architecture \\ Engineering
}

\title{
EXPERIMENTAL ANALYSIS OF CENTERALLY OPENNED TWO- WAY SLABS STRENGTHENED WITH CARBON FIBER LAMINATES
}

\author{
R. H.Abu-Zeyad ${ }^{1}$, A. A. El-Ashal ${ }^{2}$, N.H. Abdel-Mutaal ${ }^{3}$, N. H. Amer ${ }^{4}$
}

\begin{abstract}
The present study is an experimental investigation of the behavior of two-way simply supported RC flat slabs with centered circular, rectangular, and square openings. Four models were tested to failure, consisting of a reference model without opening, and three models with an opening and Carbon Fiber Reinforced Polymer (CFRP) laminates applied to the tension face of the models. The results revealed that externally bonded CFRP laminates significantly increased both the overall stiffness and flexural capacity of the models provided with an opening. CFRP anchoring method can further increase the performance of the strengthening scheme used. Experimental load-deflection curves and failure modes are discussed.
\end{abstract}

KEY WORDS: reinforced concrete; centered opening slab strengthening with Carbon Fiber Laminates; experimental analysis of two way slabs

\section{Introduction}

In many cases, openings in reinforced concrete slabs are needed to cater for installation of escalators, elevators or utilities such as air conditioning, heating or wiring ducts, rehabilitation, or other reasons. Depending on the type of upgrade, the position of the opening could be either in the positive or negative moment region of the slab, creating differing problems that could not be addressed using the same philosophy. These openings do not only reduce the strength and stiffness of the floor, but they also transform the original failure mode of the slab to some other failure patterns. Several techniques including plate bonding and fiber-reinforced polymer (FRP) systems that have been rapidly developed during the last decade may be used to restore the original strength and stiffness of the floors [1].

1. Ph.D. Candidates, M.W.D. Ministry of Defence of the Kingdom of Bahrain, Bahrain

2. Professor, Construction Research Institute, Ministry of Water Resources and Irrigation, Egypt

3. Dr., Dept. of Civil Eng., Military Technical College, Egypt

4. Dr., Dept. of Civil Eng., Military Technical College, Egypt 
Most researches in this field have been conducted to understand the behavior of slabs containing openings placed in the positive moment region to address the design issues that may rise when cutouts are created [2-4]. Over the past ten years, the problem of strengthening slabs using FRP has been addressed by researchers by substituting the previously commonlyused steel plates, thereby overcoming many problems encountered using this technique, such as weight, difficulty in handling (especially in areas where access is limited), potential corrosion, length limitations and difficulties associated with joints [5-9]. Unfortunately, these works have been mainly limited to one-way slabs. Zhang et al. studied the behavior and strength of two-way slabs externally strengthened with steel plates [10]. Erki and Heffernan presented the only study for two-way slabs with two-side supports [11]. These experiments involved square slabs, simply supported on all four sides and strengthened with CFRP laminates to enhance the punching shear capacity. This paper investigates the feasibility of restoring the original strength and stiffness lost in two-way simply supported reinforced concrete slabs due to the creation of openings. The chosen test parameters are the type of strengthening material (Carbon Fiber Reinforced Polymer), the opening location at center of models, opening shapes (circular, rectangular, and square), the ratio of area opening to that of slab affective area (8.2\%), and the type of loading (uniform loading)

\section{Experimental Work}

The models were cast and cured under laboratory conditions. The four models consisted of a reference model with no opening (RM), the first model with a circular centrally-located opening $\left(\mathrm{S}_{\mathrm{t}} \mathrm{MC} \mathrm{C}_{\mathrm{e}} \mathrm{CO}\right)$, the second model with a rectangular centrally-located opening $\left(\mathrm{S}_{\mathrm{t}} \mathrm{MC}_{\mathrm{e}} \mathrm{R}_{\mathrm{e}} \mathrm{O}\right)$, and the third model with a square centrally-located opening $\left(\mathrm{S}_{\mathrm{t}} \mathrm{MC} \mathrm{C}_{\mathrm{e}} \mathrm{S} \mathrm{O}\right)$. For the last three models, CFRP laminates were applied at the tension face. Table 1 summarizes the overall dimensions of the four two-way simply supported models constructed for this experimental samples program. Samples of the rebar, CFRP arrangement and models geometry and photos are shown in Figure 1-a, and 1-b. Material properties of the concrete and steel bars are given in Table 2.

Models $\mathrm{S}_{\mathrm{t}} \mathrm{MC} \mathrm{C}_{\mathrm{e}} \mathrm{CO}, \mathrm{S}_{\mathrm{t}} \mathrm{MC}_{\mathrm{e}} \mathrm{R}_{\mathrm{e}} \mathrm{O}$, and $\mathrm{S}_{\mathrm{t}} \mathrm{MC}_{\mathrm{e}} \mathrm{S}_{\mathrm{q}} \mathrm{O}$ were strengthened using one layer per laminates of unidirectional carbon FRP laminate. Each layer was $5 \mathrm{~cm}$ wide, $130 \mathrm{~cm}$ length, and $0.12 \mathrm{~cm}$ in thickness. The amount of CFRP used to strengthen slabs was computed under the promise that the loss of steel reinforcement caused by the cutout would be replaced by an equivalent amount of CFRP according to equation (1) [12]

Table1-The total number of CFRP applied and the laminates length for each slab

\begin{tabular}{|c|c|c|c|c|c|c|c|c|c|}
\hline \multirow[t]{2}{*}{ Models } & \multirow[t]{2}{*}{$\begin{array}{c}\text { Dimension } \\
\text { of slab, } \\
\text { M }\end{array}$} & \multirow[t]{2}{*}{$\begin{array}{c}\text { Cutout } \\
\text { Dimension, } \\
\text { M }\end{array}$} & \multirow[t]{2}{*}{$\begin{array}{c}\text { (Cutout Area)/ } \\
\text { (Total Effe. area) } \\
\%\end{array}$} & \multicolumn{2}{|c|}{$\begin{array}{l}\text { \# of Steel Reinforcement } \\
\text { bars lost in the cutout in } \\
\text { each direction }\end{array}$} & \multicolumn{2}{|c|}{$\begin{array}{l}\text { CFRP } \\
\text { Strengthening } \\
\text { along each side } \\
\text { of the opening }\end{array}$} & \multicolumn{2}{|c|}{$\begin{array}{l}\text { Length of } \\
\text { CFRP } \\
\text { Required } \\
\text { in each } \\
\text { direction } \\
\text { m }\end{array}$} \\
\hline & & & & $\begin{array}{c}\mathrm{X} \\
\text { direction }\end{array}$ & $\begin{array}{c}\mathbf{Y} \\
\text { direction }\end{array}$ & $\begin{array}{c}\mathrm{X} \\
\text { direction }\end{array}$ & $\begin{array}{c}\mathbf{Y} \\
\text { direction }\end{array}$ & $\begin{array}{c}\mathrm{X} \\
\text { direction }\end{array}$ & $\begin{array}{c}\mathbf{Y} \\
\text { direction }\end{array}$ \\
\hline $\mathbf{R M}$ & $1.5 \times 1.5 \times 0.06$ & ------ & ------ & ------ & ------ & ------ & ------ & ------ & ------ \\
\hline $\mathrm{S}_{\mathrm{t}} \mathbf{M C}_{\mathrm{e}} \mathrm{CO}$ & $1.5 \times 1.5 \times 0.06$ & $r=0.225$ & 8.2 & 2 & 2 & 1 & 1 & 1.3 & 1.3 \\
\hline $\mathrm{S}_{\mathrm{t}} \mathbf{M C}_{\mathrm{e}} \mathbf{R}_{\mathrm{e}} \mathrm{O}$ & $1.5 \times 1.5 \times 0.06$ & $0.55 \times 0.30$ & 8.2 & 2 & 2 & 1 & 1 & 1.3 & 1.3 \\
\hline $\mathrm{S}_{\mathrm{t}} \mathbf{M C}_{\mathrm{e}} \mathrm{S}_{\mathrm{q}} \mathrm{O}$ & $1.5 \times 1.5 \times 0.06$ & $0.40 \times 0.40$ & 8.2 & 2 & 2 & 1 & 1 & 1.3 & 1.3 \\
\hline
\end{tabular}




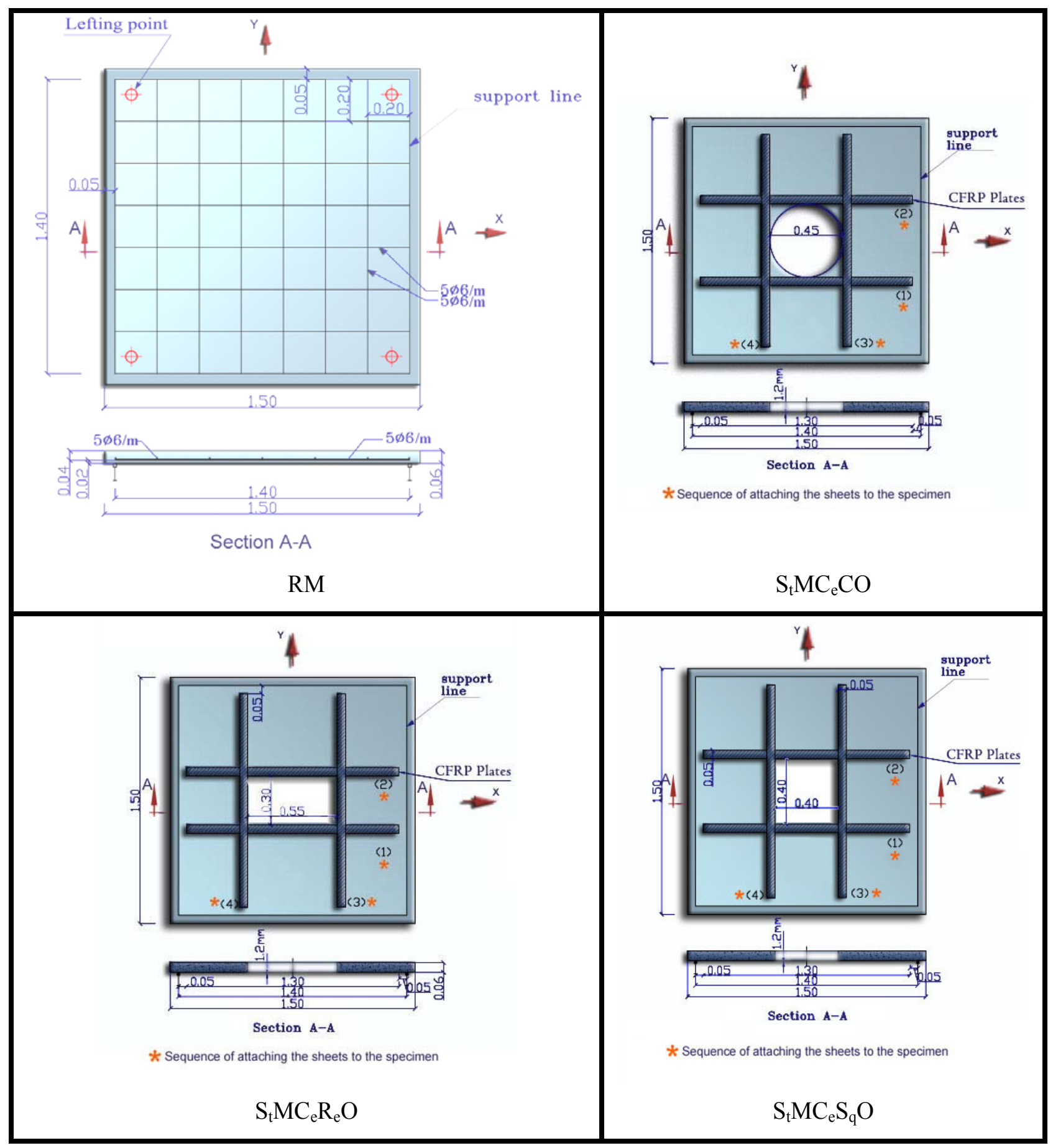

Figure 1-a Layout of rebar, CFRP arrangement and model geometry 


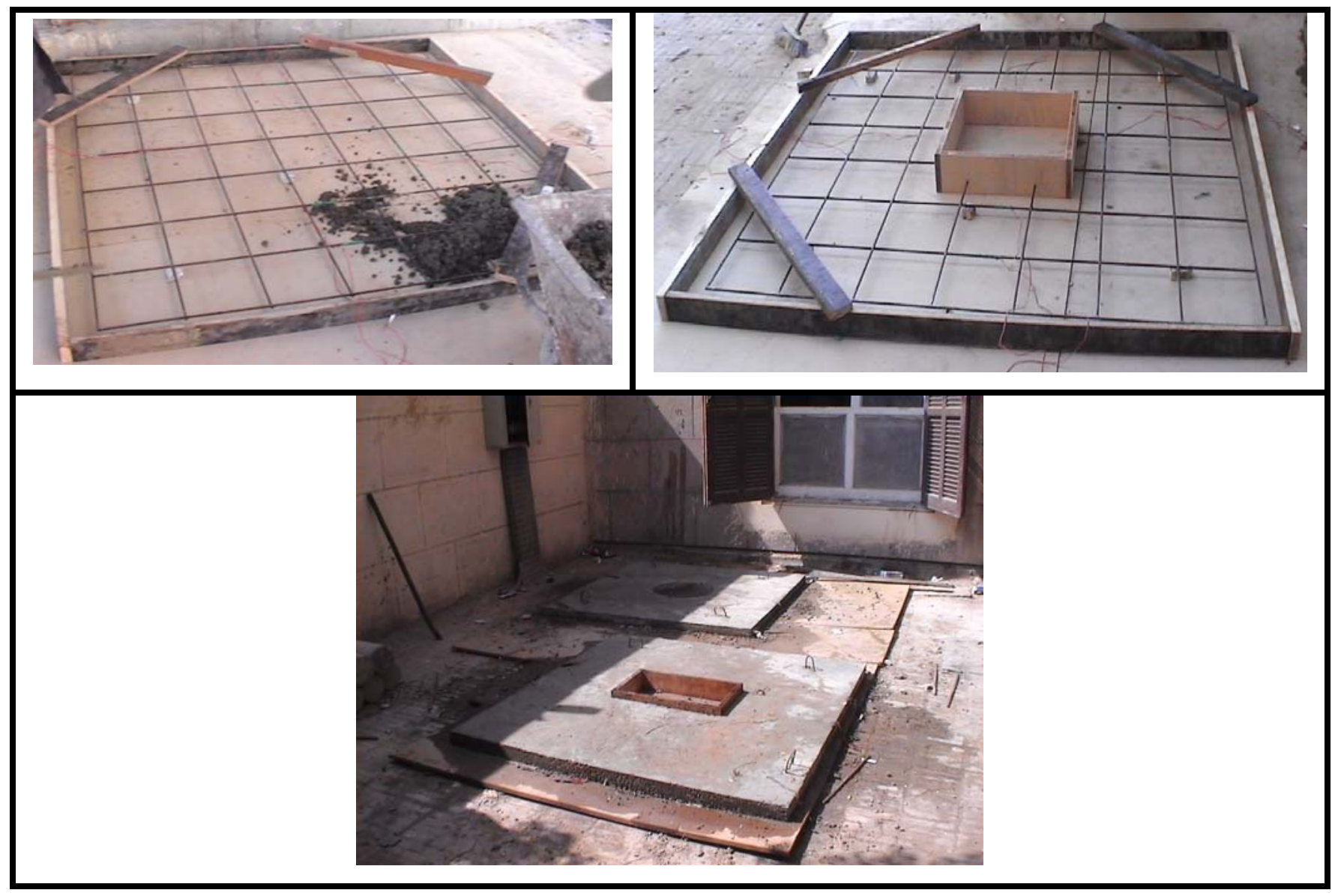

Figure 1-b Sample photos of models

Table 2 - Properties of Used Materials

\begin{tabular}{|c|c|c|c|c|c|}
\hline \multirow[t]{2}{*}{ Material } & \multicolumn{2}{|c|}{$\begin{array}{l}\text { cubic compressive } \\
\text { strength }^{(1)}, \mathrm{MPa}\end{array}$} & \multirow{2}{*}{$\begin{array}{l}\text { Yield strength, } \\
\qquad \mathrm{MPa}\end{array}$} & \multirow{2}{*}{$\begin{array}{c}\text { Modulus of } \\
\text { elasticity, } \\
\mathrm{GPa}\end{array}$} & \multirow{2}{*}{$\begin{array}{c}\text { Cross section of rebar used, } \\
\qquad \text { As } \mathrm{mm}^{2}\end{array}$} \\
\hline & 7 days & 28days & & & \\
\hline Concrete $^{(2)}$ & 23 & 30 & Not applicable & 22.5 & Not applicable \\
\hline Steel $^{(3)}$ & & & 325 & 200 & 28.7 \\
\hline
\end{tabular}

(1) Tested at 7 and 28 days when all the models were tested.

(2) Average of 6 models [ $15.24 \mathrm{~cm} \times 30.48 \mathrm{~cm}$ cylinders].

(3) Average of 6 models [91.44 cm long] 


$$
\frac{E_{s} \times A_{s}^{\text {lost }}}{E_{f} \times A_{f}}=1
$$

Where,

$\mathrm{E}_{\mathrm{s}} \quad=$ elasticity modulus of steel,

$\mathrm{A}_{\mathrm{s}}^{\text {lost }}=$ steel area lost,

$\mathrm{E}_{\mathrm{f}} \quad=$ elasticity modulus of CFRP,

$\mathrm{A}_{\mathrm{f}} \quad=$ CFRP area

The amount of steel reinforcement lost is equivalent to:

$$
\mathrm{A}_{\mathrm{s}}^{\text {lost }}=\mathrm{N} \times \mathrm{A}_{\mathrm{s}}
$$

Where, $\mathrm{N}$ is the number of steel bars, which have been cut. Substituting into equation (1) we can compute the equivalent area of CFRP:

$$
A_{\mathrm{f}}=\frac{\mathrm{E}_{\mathrm{s}}}{\mathrm{E}_{\mathrm{f}}} \times \mathrm{A}_{\mathrm{s}}^{\text {lost }}
$$

Since each layer has a nominal width $b f=50 \mathrm{~mm}$, the necessary overall thickness of CFRP laminate is given by:

$$
\mathrm{t}_{\mathrm{tot}}=\frac{\mathrm{A}_{\mathrm{f}}}{\mathrm{b}_{\mathrm{f}}}
$$

Given that thickness of one layer, $t^{\prime}=1.2 \mathrm{~mm}$, the total number of layers required is:

$$
n^{\prime}=\frac{t_{\text {total }}}{t^{\prime}}
$$

A total of two layers were applied as shown in figure 2. One was placed along one side of the cutout and the other along the other side in each direction. The development length of the laminates was calculated by equating the bond strength to its yield capacity as follows: [13]. 


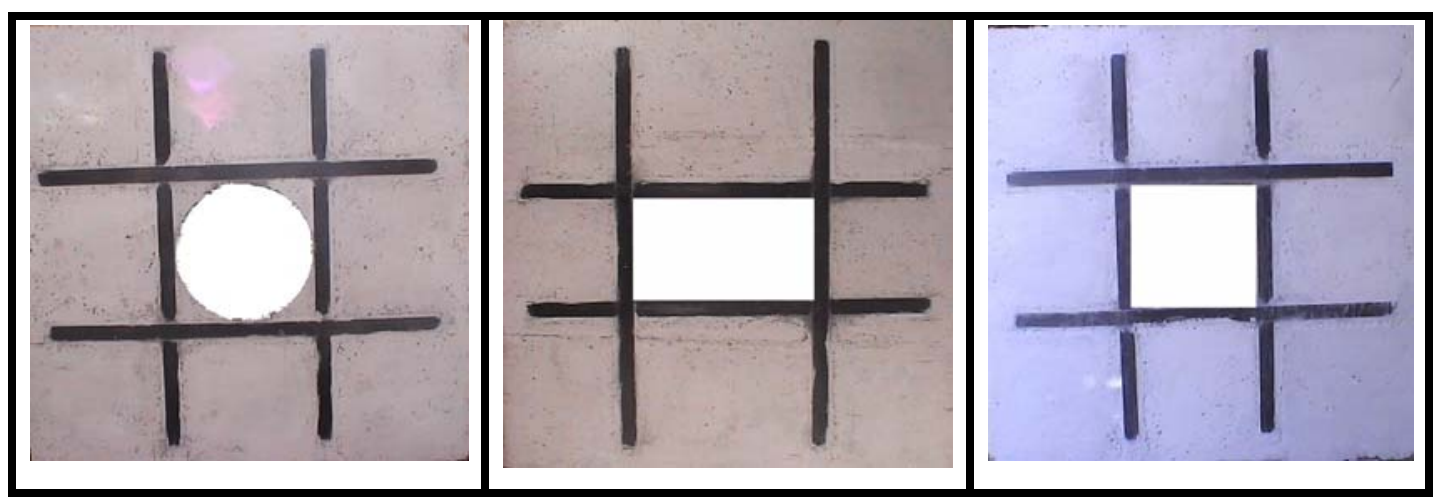

Figure 2-CFRP Laminates on tension face of models with opening

$$
\mathrm{L}_{\mathrm{d}} \times \mathrm{b}_{\mathrm{s}} \times \mathrm{f}_{\mathrm{b}, \mathrm{s}}=\mathrm{A}_{\mathrm{s}} \times \mathrm{f}_{\mathrm{y}, \mathrm{s}}
$$

Where,

$\mathrm{L}_{\mathrm{d}} \quad=$ strip length beyond opening edge

$b_{s}, A_{s}=$ strip breadth and cross sectional area

$\mathrm{f}_{\mathrm{y}, \mathrm{s}} \quad=$ yield capacity of the strip

$\mathrm{f}_{\mathrm{b}, \mathrm{s}}=$ bond strength of the cover concrete $[14]=0.3 * \sqrt{\frac{\mathrm{f}_{\mathrm{cu}}}{\gamma_{\mathrm{c}}}}$

The bonding process used for the CFRP laminates was as follow. The tension face of the models was abraded by sandblasting to remove all the laitance and to expose the aggregate before bonding. Then, the surface was thoroughly brushed to remove all loose particles. Once the surfaces had been prepared, CFRP laminates were bonded to the tension face by using epoxy resin. In order to avoid any concentrated unevenness in the location in which the layers overlapped on the four diagonals, the layers in the two perpendicular directions were applied one at a time in sequence as shown in Figure 1-a. The laminates were bonded adjacent to the edge of the opening in order to resist the localized peak stresses occurring near the corners of openings. The mechanical characteristics of the CFRP laminates are presented in Table 3.

Table 3 - Properties of CFRP Constituent Materials

\begin{tabular}{|c|c|c|}
\hline Property & $\begin{array}{c}\text { CarboDur S512 } \\
\text { Manufacturer Data }\end{array}$ & $\begin{array}{c}\text { CarboDur S512 } \\
\text { Experimental Data* }\end{array}$ \\
\hline E-modulus & $165,000 \mathrm{~N} / \mathrm{mm}^{2}$ & $172,000 \mathrm{~N} / \mathrm{mm}^{2}$ \\
\hline Tensile Strength & $2,800 \mathrm{~N} / \mathrm{mm}^{2}$ & $1,517 \mathrm{~N} / \mathrm{mm}^{2}$ \\
\hline Strain at Failure & $>1.7 \%$ & $>0.9 \%$ \\
\hline Poisson's Ratio & --- & 0.266 \\
\hline
\end{tabular}

$*_{\text {initial crack appeared at } 841 \mathrm{~N} / \mathrm{mm}^{2}}$ 


\section{Experimental Setup:}

The models were tested under simply supported conditions and subjected to uniform load. A 30-tons capacity hydraulic jack, activated by a manual pump, was used to load each test specimen. The force generated by the hydraulic jack was transferred to the specimen by rigid steel plates placed above each other on the upper surface of the slab. The rigid steel plates were $60 \times 60 \times 2.5 \mathrm{~cm}, 45 \times 45 \times 3 \mathrm{~cm}, 15 \times 15 \times 10 \mathrm{~cm}$, and $25 \mathrm{~cm}$ in Dia.x $5 \mathrm{~cm}$ thicknesses, respectively. The experimental setup is shown in Figure 3. The load was applied with an increment of 0.2 ton rate up to failure load. For the reference model, a total of five dial gauges were used to record slab deflections, and four electrical strain gauges of $5 \mathrm{~mm}$ length were installed on the steel reinforcement. For all strengthened models, a total of five dial gauges were used to record slab deflection. Two electrical strain gauges of $5 \mathrm{~mm}$ length were installed on the CFRP. All electrical strain gauges were manufactured by Kyowa, Japan of type KFG-5-120-C1-11L1M2R, with nominal resistance of $120 \mathrm{ohms}$ and gauges length of $5 \mathrm{~mm}$. The strain gauges were attached to the steel using strain gage cement manufactured by Kyowa, Japan of type CC-33A then insulated from the wet concrete by means of silicon coating. The data was recorded at every incremental load.

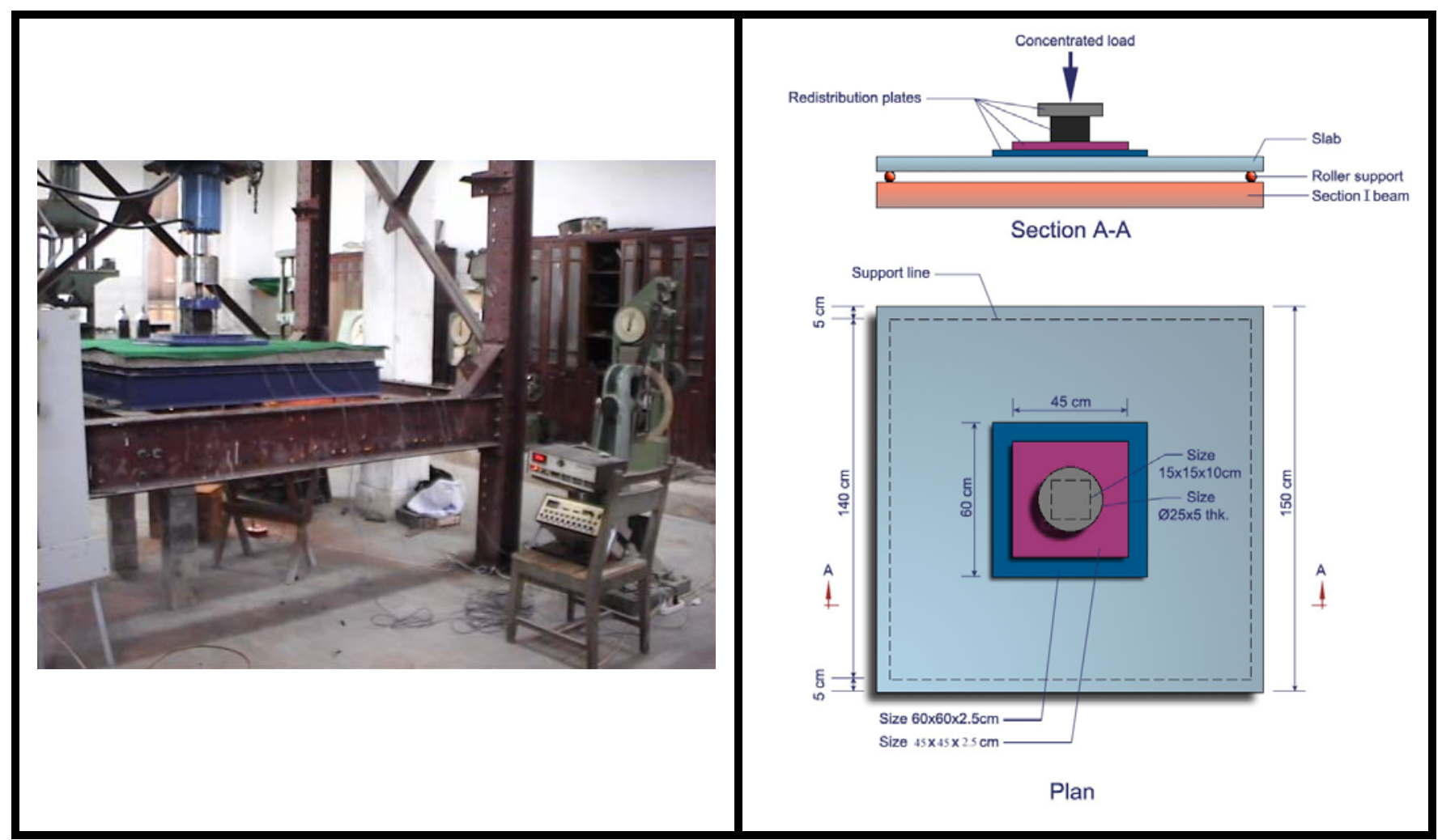

Figure 3 - Test Setup

\section{Results and Analysis:}

All models showed flexure failure due to steel yield. Reference model (RM) exhibited moderate crushing, extensive cracks and deflection prior to flexural failure by concrete 
crushing. In all strengthened models $\left(\mathrm{S}_{\mathrm{t}} \mathrm{MC} \mathrm{C} \mathrm{CO}, \mathrm{S}_{\mathrm{t}} \mathrm{MC}_{\mathrm{e}} \mathrm{R}_{\mathrm{e}} \mathrm{O}, \mathrm{S}_{\mathrm{t}} \mathrm{MC} \mathrm{C}_{\mathrm{e}} \mathrm{S} \mathrm{O}\right)$, failure was caused by sudden peeling of the bonding system at the end of laminates, with a considerable amount of concrete substrate. Table 4 summarizes the test results, while Figure 4 shows images of the crack and failure modes in two faces of models.

Table (4) Test results for models

\begin{tabular}{|c|c|c|c|}
\hline Models & Failure load (KN) & $\begin{array}{c}\text { Load capacity } \\
\text { Enhancement } \\
(\%)\end{array}$ & $\begin{array}{c}\text { Load at first yield } \\
\text { of steel } \\
\text { reinforcement }(\mathrm{KN})\end{array}$ \\
\hline $\mathrm{RM}$ & 42.0 & --- & 8.0 \\
$\mathrm{~S}_{\mathrm{t}} \mathrm{MC}_{\mathbf{e}} \mathrm{CO}$ & 78.0 & 85.7 & 12.0 \\
$\mathrm{~S}_{\mathrm{t}} \mathrm{MC}_{\mathrm{e}} \mathrm{R}_{\mathrm{e}} \mathrm{O}$ & 48.0 & 14.3 & 8.0 \\
$\mathrm{~S}_{\mathrm{t}} \mathrm{MC}_{\mathrm{e}} \mathrm{S}_{\mathrm{q}} \mathrm{O}$ & 68.0 & 61.9 & 12.0 \\
\hline
\end{tabular}

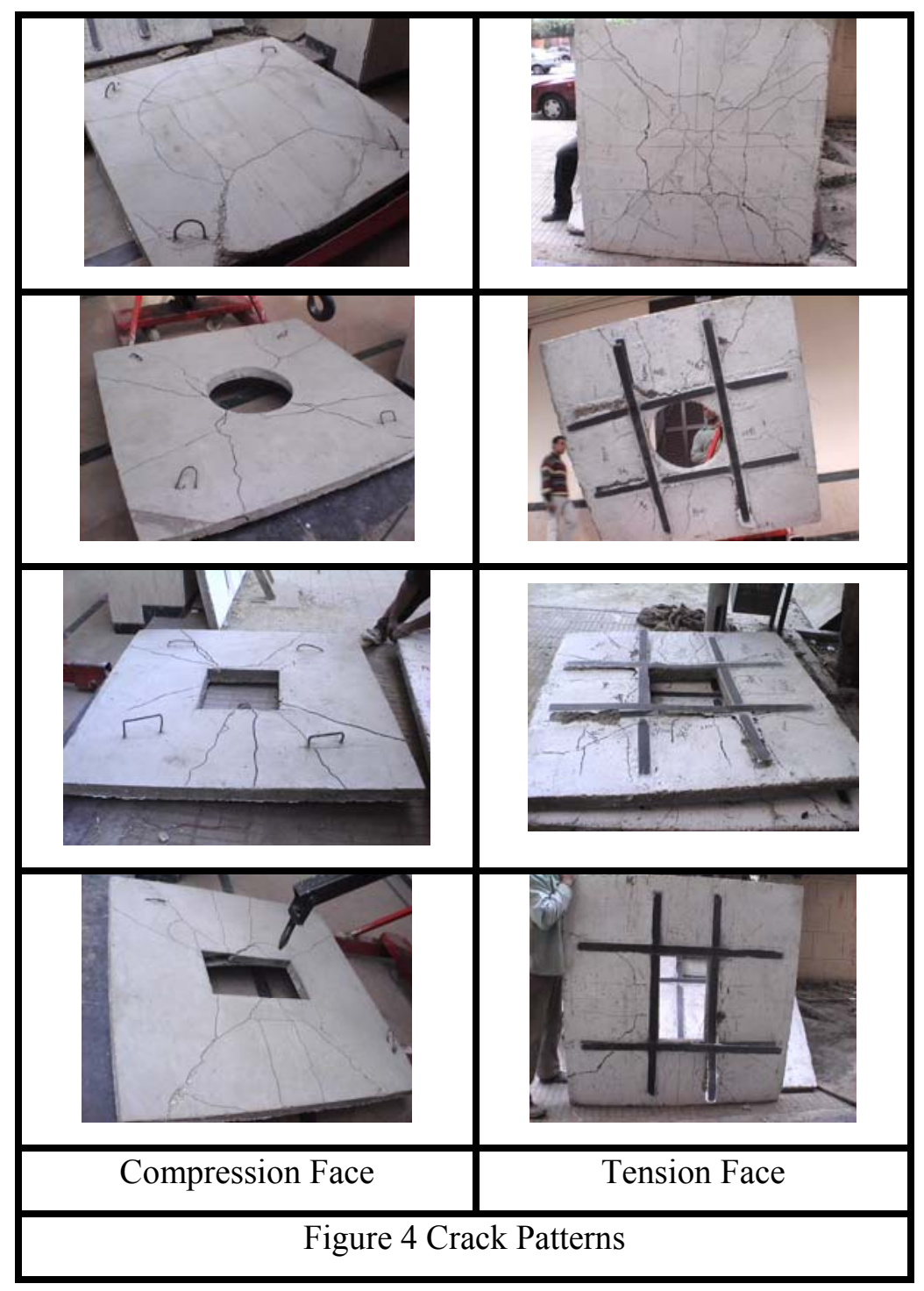


Flexural cracks started either at the center of the RM or along the edges of the cutouts of $\mathrm{S}_{\mathrm{t}} \mathrm{MC}_{\mathrm{e}} \mathrm{CO}, \mathrm{S}_{\mathrm{t}} \mathrm{MC}_{\mathrm{e}} \mathrm{R}_{\mathrm{e}} \mathrm{O}, \mathrm{S}_{\mathrm{t}} \mathrm{MC}_{\mathrm{e}} \mathrm{S}_{\mathrm{q}} \mathrm{O}$, developing perpendicular to the adjacent line of support. Under increasing of load, these cracks developed diagonally towards the support corners, symmetrically located across the entire tension face (see Figure 4). On the top surface, crushing developed in a circular pattern around the loading area. Also, linearly from the application load at roughly a $45^{\circ}$ angle towards the lines of support (see Figure 4). This pattern was repeated in all slabs and occurred more evidently at high levels of load. In all slabs, flexural-shear cracks developed along the sides at a $45^{\circ}$ angle, connecting the bottom flexural cracks with the top-surface ones as shown in Figure 5. In strengthened slabs, similar types of crack developed on the sides of the openings, starting from the corners of the hole and moving at an angle of $45^{\circ}$ approximately towards the center of the cutout as shown in Figure 4-b.

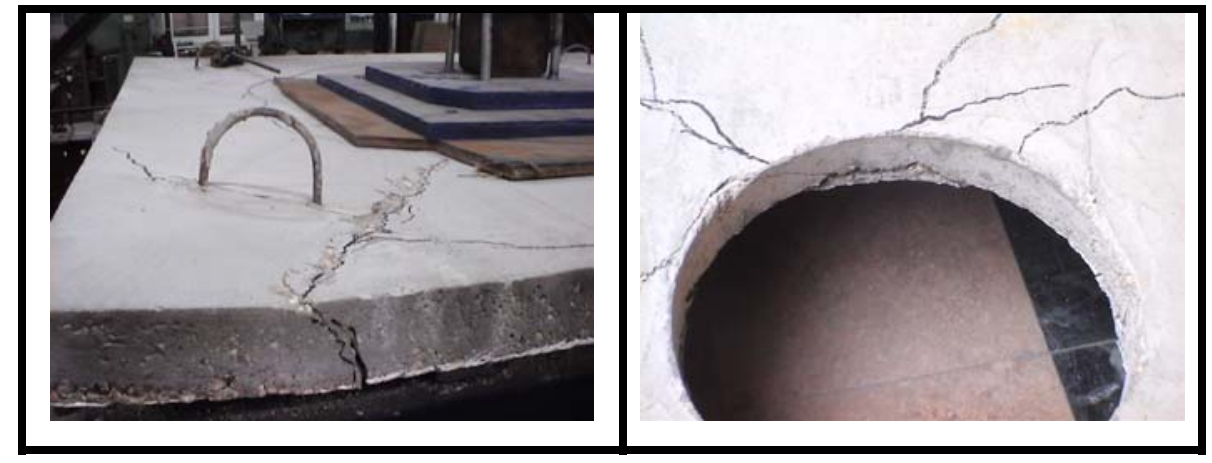

Figure 5 - Shear crack in $\mathrm{RM}$ and $\mathrm{S}_{\mathrm{t}} \mathrm{MC}_{\mathrm{e}} \mathrm{CO}$

Post-failure inspection showed that these cracks sliced through the plane of the slab, which may be interpreted as a form of punching shear behavior. The simply supported conditions under which these tests were performed helped to encourage a more flexural type of behavior at the expense of such punching shear. If the four corners of the slab had been restrained from lifting up, it is possible that punching shear would have been the definitive controlling mode of failure. All strengthened slabs experienced a very similar crack pattern, but failure of the models occurred in the sudden peeling of the CFRP. De-bonding of the laminates started from flexural cracks at the maximum bending moment region around the hole, and particularly in the area where the two perpendicular strips overlapped on the diagonal (see Figure 6), but the epoxy bonding prevented the laminates from de-bonding prematurely. At failure, the entire concrete cover was pulled off suddenly (see Figure 6).

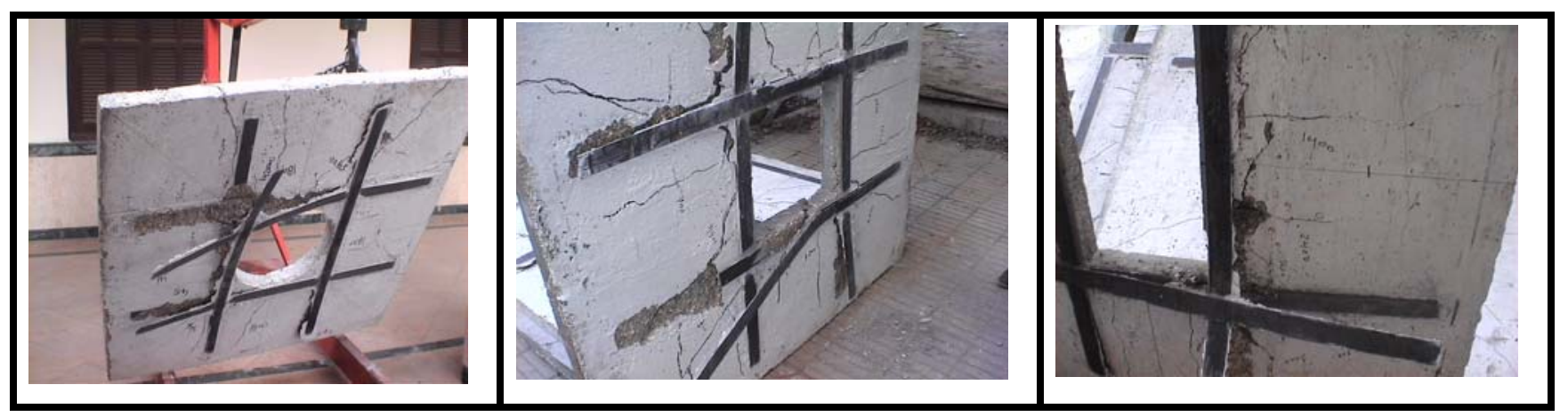

Figure 6 Failure of epoxy bonding: pull off the concrete cover 
Figures 7-a, 7-b, and 7-c show the load vs deflection curves at the maximum deflection point for the RM and strengthened models for circular opening, rectangular opening, and square opening, respectively. While Figure 7-d shows the load vs deflection curves for the RM and all strengthened models with the deflection measured at maximum deflection point. Figures 8-a shows the maximum deflection values for RM and all strengthened models, while Figure 8-b shows the initial cracks load and ultimate loads for RM and all strengthened models. Figures 9-a, 9-b, 9-c and 9-d show the load vs strain curves for the RM, $\mathrm{S}_{\mathrm{t}} \mathrm{MC} \mathrm{C}_{\mathrm{e}} \mathrm{CO}, \mathrm{S}_{\mathrm{t}} \mathrm{MC}_{\mathrm{e}} \mathrm{R}_{\mathrm{e}} \mathrm{O}$, and $\mathrm{S}_{\mathrm{t}} \mathrm{MC}_{\mathrm{e}} \mathrm{S}_{\mathrm{q}} \mathrm{O}$ respectively. While Figures $10-\mathrm{a}, 10-\mathrm{b}, 10-\mathrm{c}$ and 10-d show the load vs strain curves for the $\mathrm{RM}, \mathrm{S}_{\mathrm{t}} \mathrm{MC}_{\mathrm{e}} \mathrm{CO}, \mathrm{S}_{\mathrm{t}} \mathrm{MC}_{\mathrm{e}} \mathrm{R}_{\mathrm{e}} \mathrm{O}$, and $\mathrm{S}_{\mathrm{t}} \mathrm{MC}_{\mathrm{e}} \mathrm{S}_{\mathrm{q}} \mathrm{O}$ respectively.

It could be noticed from Figures 7-a to 8-b that all strengthened models exhibited higher initial cracks and ultimate load compared to the reference model. The initial crack load increased by $100 \%, 75$, and $50 \%$ for slabs with circular openings, rectangular openings, and square openings, respectively. The ultimate load increased by $85.7 \%, 14.3 \%$, and $61.9 \%$ for models with circular openings, rectangular openings, and square openings, respectively.

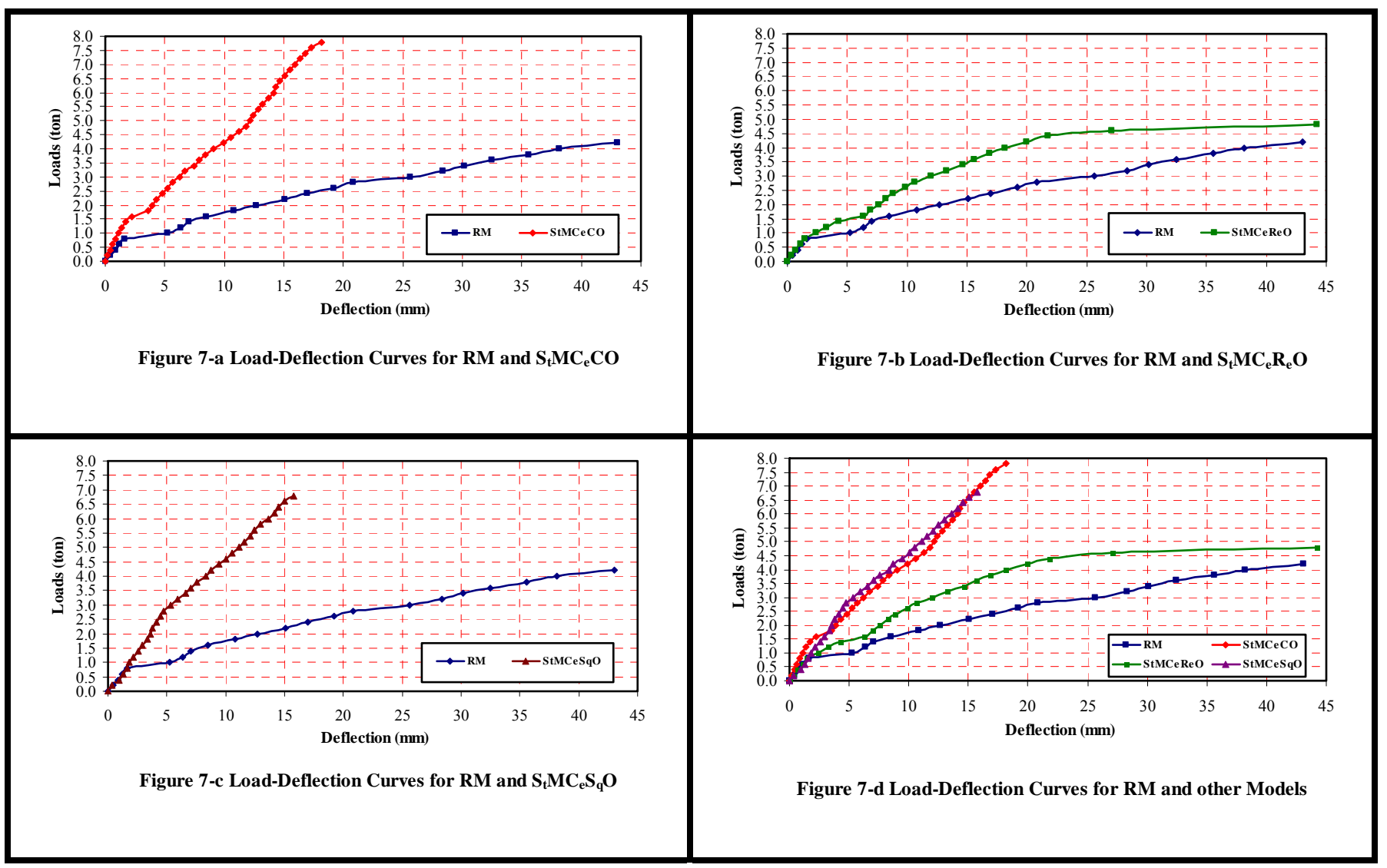


Proceedings of the 6th ICCAE Conf. 16 -18 May, 2006
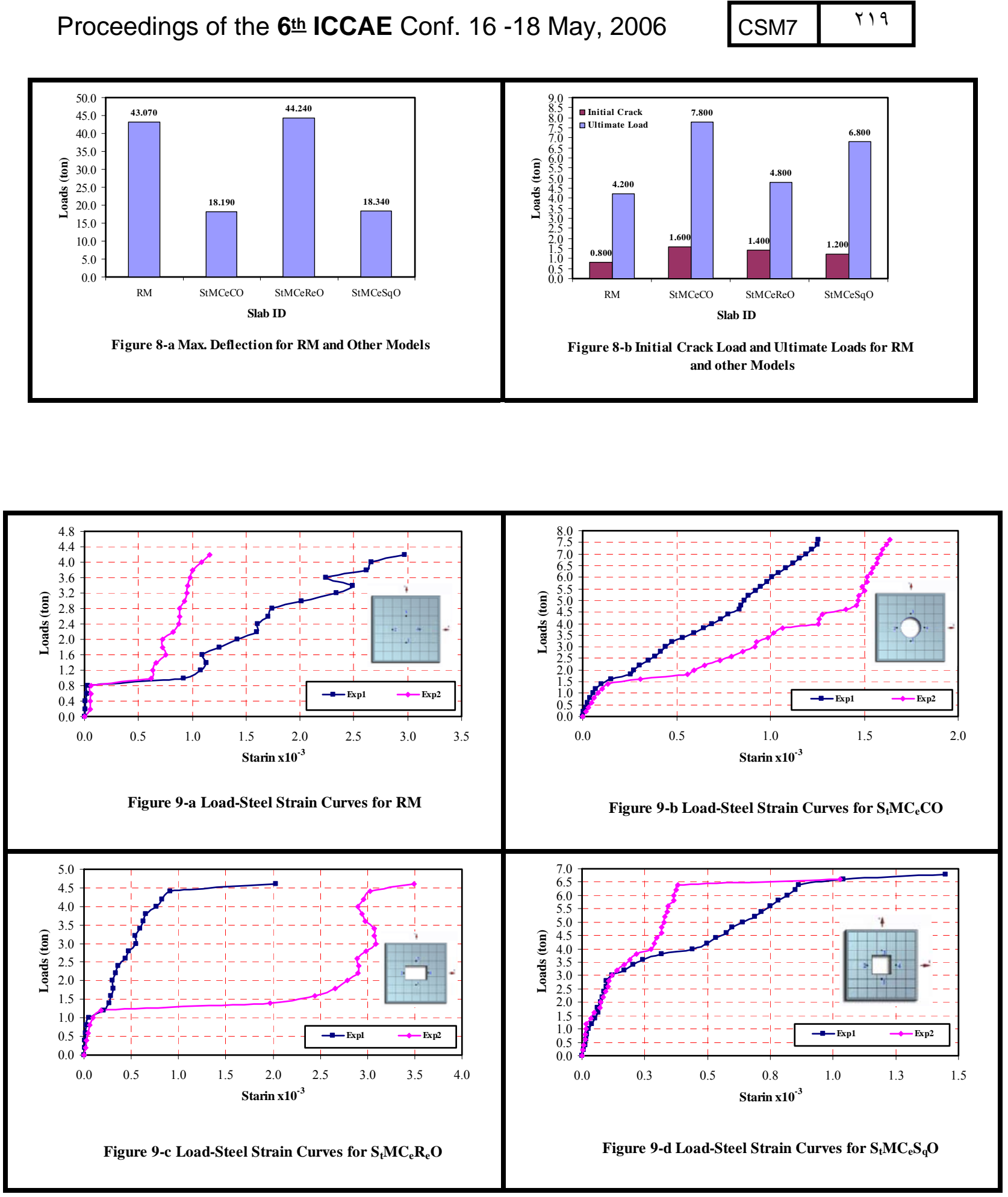


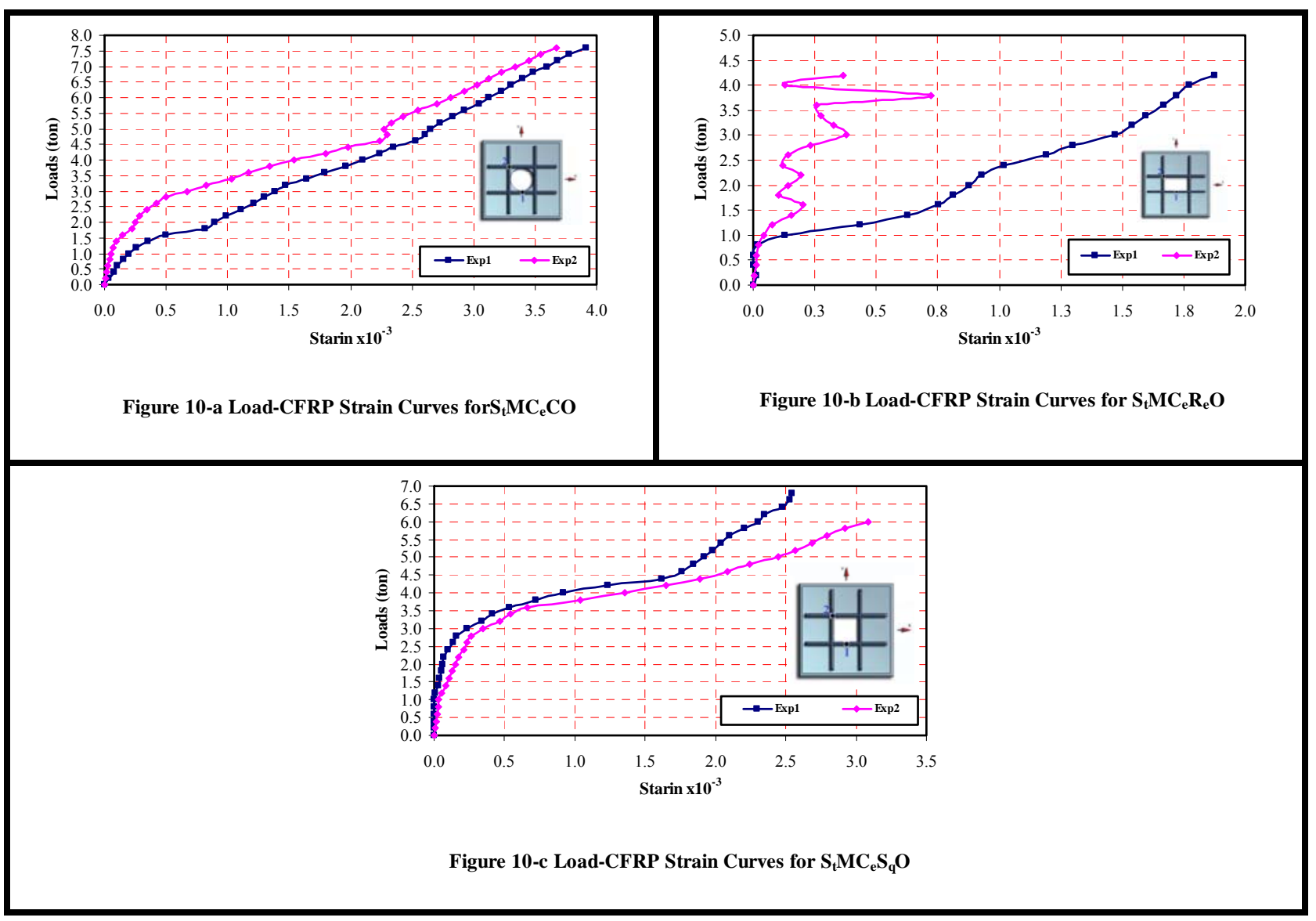

\section{Conclusions}

The following conclusions may be drawn from this experimental program:

1) CFRP laminates have proved to be effective technique for recovery of model capacity due to existence of opening for all different shapes at center locations.

2) A great care should be taken into consideration in bonding CFRP laminates at the edges to avoid premature de-bonding of the CFRP laminates.

3) For the same opening area ratio and the chosen location, circular opening shape showed the best behavior and model capacity relative to square and rectangular openings.

4) Strengthened model for circular shape enhanced the capacity by $100 \%$ for initial crack load, and $85.7 \%$ for ultimate load. While the enhancement percents were $75 \%$, and $14.3 \%$, respectively for rectangular shape and $50 \%$, and $61.9 \%$ respectively for square shape.

\section{References}

1) ACI Committee 440R, "State of the Art Report on Fiber Reinforced Plastic (FRP) reinforcement for Concrete Structures", American Concrete Institute, 1996.

2) Zaslvasky, A. (1967). "Yield-Line Analysis of Rectangular Slabs with Central Openings," Proceedings ACI, Vol. 64, 838-844.

3) Lash, S.D., Banerjee, A. (1967). "Strength of Simply Supported Square Plates with Central Square Openings,” Trans. Eng. Inst. Can., Vol. 10, No. A-5, 3-11.

4) Islam, S. and Park, R. (1971). "Yield-Line Analysis of Two-way RC Slabs with 
Openings,” J. Inst. Structure Eng., Vol. 49, No. 6, 269-276.

5) Ichimasu, H., Maruyama, M., Watanabe, H., and Hirose, T. (1993). "RC slabs strengthened by bonded carbon FRP plates: Part 1-Laboratory Study," FRPRCS, ACI SP-138, A. Nanni, and C. W. Dolan, 933-955.

6) Arockiasamy, M., Sowrirajan, R., Shahawy, M. and Beitelman, T. E., (1995) "Concrete Beams and Slabs Retrofitted with CFRP Laminates", Proc. Of 11th Conf. on Eng. Mech., ASCE, New York, 776-779.

7) Karbhari, V. M., Seible, F., Seim, W., and Vasquez, A. (1999). "Post-strengthening of concrete slabs," FRPRCS4, ACI SP-188, C. W. Dolan, S. H. Rizkalla and A. Nanni, American Concrete Institute, 1163-1173.

8) Takahashi, Y., and Sato, Y. (2001). "Experimental study on the strengthening effect of a CFRP sheet for RC slabs," FRPRCS5, Thomas Telford, Cambridge, UK, 989-996.

9) Teng, J.G., Chen, J.F., Smith, S.T., and Lam, L. (2002) "Flexural Strengthening of Slabs," FRP Strengthened RC Structures, John Wiley \& Sons, 135-146.

10) Zhang, J. W., Teng, J. G., Wong, Y. L., and Lu, Z. T. (2001). "Behavior of two-way RC slabs externally bonded with steel plate," Journal of Structural Engineering, ASCE, Vol. 127, No. 4, 390-397.

11) Erki, M.A., and Heffernan, P.J., (1995). "Reinforced Concrete Slabs Externally Strengthened with Fibre-Reinforced Plastics Materials", Non-metallic (FRP) Reinforcement for Concrete Structures, 2nd Symposium, Belgium, pp.509-516.

12) Casadei P., Nanni, A. and Ibell T., "Experiments on Two-way RC Slabs with Openings Strengthened with CFRP Laminates", Center for Infrastructure Engineering Studies, (CIES03-39), University of Missouri-Rolla, USA, 2003.

13) Mohamed, T., El-Attar, A., and El-Ibiari, S., (2002). "Strengthening of Two-Way Reinforced Concrete Slabs with Created Central Openings" Accepted to the III Regional Conference on Civil Engineering Technology and III International Symposium on Environmental Hydrology, Egypt.

14) Egyptian Code for Design and Construction of Reinforced Concrete Structures (ECCS, 2001), Ministerial Decree No. 203, 2001. 